\title{
Study of the influence of the feeding type of calves during the milk fattening period on the subsequent growth and development of bulls up to 12 months of age
}

\author{
Valentin Golovan, Denis Osepchuk, Denis Yurin*, and Aleksey Kucheryavenko \\ Krasnodar Research Centre for Animal Husbandry and Veterinary Medicine, 350055, Krasnodar, \\ Russian Federation
}

\begin{abstract}
Research has been carried out on the intensive production of beef when raising dairy bulls up to 12 months of age drinking mainly dairy feed in the first 5 months of life (in group 1) and with the inclusion of a starter compound feed in the diet (in group 2). Different types of bull calves rearing in the first 5 months of life led to significant differences in the growth and development of the whole organism and all its individual organs and tissues, mainly in favour of bull calves raised with replacing part of the milk with vegetable feed, and subsequently had a decisive influence in the period from 6 up to 12 months of their life with the same type of feeding and maintenance. It has been established that the rearing system with a decrease in the drinking of whole milk and abstinence of the supply of roughage for the first 2 months of life, promotes the the growth of animals for a twelve-month period of life, leads to an increase in the yield of veal and beef meat, a decrease in feed consumption per unit of weight gain, and increasing the profitability of production by $8-9 \%$, therefore it is recommended for production.
\end{abstract}

\section{Introduction}

A key objective of livestock research is to improve animal productivity and meat quality, taking into account efficient sustainable production and consumer preferences. Therefore, new strategies are being developed, such as the inclusion of various plant components.

Beef is a valuable dietary food; it contains complete, easily digestible proteins. The muscle tissue of beef obtained from bulls at 12 months of age is low in fat (1.0-3.8\%), so it can be included in the diet of people as a dietary product.

The palatability of beef obtained from young animals significantly depends on how the calves are fed and at what age they were slaughtered. Usually, the calf begins to switch to solid food at the age of 2-3 months, but it can be weaned from milk later [1-6].

The best beef is obtained from young cattle at 12 months of age, which, for a quick weight gain, is kept on intensive fattening with milk or its substitutes at the age of 4-5 months. The technology is attractive because of its low feed costs per $1 \mathrm{~kg}$ of gain (4.2 EFU

\footnotetext{
*Corresponding author: 4806144@mail.ru
} 
with intensive, with medium-intensive technology - 4.37 EFU), compared to beef 8-10.0 EFU in bulls aged 15-18 months.

Calves of dairy breed can be used for beef production. It is recognized that a premium milk-fat calf should be fed entirely with whole milk, or, as a last resort, should receive limited amounts of hay and concentrates. First, the calf is given 4.5-5.5 kg of milk per day, and this amount is gradually increased when fed twice.

The determining factor in the colour of meat is the content of myoglobin. If the meat is white - there is very little myoglobin, pink (red) - the amount of myoglobin is high.

The rise in the cost of conventional feed has led beef producers to adopt more costeffective production methods and seek new sources of protein and energy [7-12].

\section{Methodology}

The purpose of the research is to develop elements of technology for intensive production of beef when raising bulls of dairy breed up to 12 months of age with the inclusion of compound feed - a starter in the diet and drinking different amounts of milk feed in the first 5 months of life.

Research novelty. New knowledge has been gained about the intensive production of beef when raising bulls of dairy breed up to 12 months of age with drinking different amounts of milk feed in the first 5 months of life and including a starter in the ration.

Base and research methods. Research was carried out in the conditions of the economy of the Krasnoarmeisky breeding farm named after A.I. Maistrenko, Krasnoarmeisky district, Krasnodar Territory.

For the experiment, bull calves of the Black-and-White Holstein breed from 4 days of age were selected, divided into 2 groups of 12 heads each (Table 1 ).

The bull calves of the first group (control) were raised mainly on milk. The second group of animals received whole milk for 5 months, only 4-6 kg / head/ day plus a starter compound feed developed at the Krasnodar Research Centre for Animal Husbandry and Veterinary Medicine (KRCAHVM) and a small amount of alfalfa hay. Later, up to 12 months of age, the feeding of animals of both groups was the same.

Table 1. Experimental design (up to 12 months of life) ( $n=12$ heads per group)

\begin{tabular}{|c|c|c|}
\hline Age & Group \\
\hline Group & 1 (control) & 2 (experimental) \\
\hline \multirow{2}{*}{$\begin{array}{c}1-5 \\
\text { months }\end{array}$} & $\begin{array}{c}\text { Whole milk 6-12 kg } \\
\text { per day }\end{array}$ & Whole milk 4-6 kg per day \\
\cline { 2 - 3 } & $\begin{array}{c}\text { Alfalfa hay from the } \\
2^{\text {nd }} \text { month 0.5-1 kg }\end{array}$ & $\begin{array}{c}\text { Starter compound feed } \\
\text { (KRCAHVM) from day 7 on } \\
\text { consumption up to 2.5 kg }\end{array}$ \\
\cline { 2 - 3 } & \multicolumn{2}{|c|}{$\begin{array}{c}\text { From the 3rd month: } \\
\text { alfalfa hay 0.5-2.0 kg }\end{array}$} \\
\hline $\begin{array}{c}6-12 \\
\text { months }\end{array}$ & \multicolumn{2}{|c|}{ Hay, silage, haylage, compound feed } \\
\hline
\end{tabular}

Up to 2 months of age, the calves were kept in individual cages, and after the bulls were transferred to group cages of 5-6 heads each. Here, a device is used to protect against solar radiation in hot weather. Watering of animals is carried out when kept in houses - from a bucket, in cages - from group drinkers.

The starter compound feed contained in $1 \mathrm{~kg}$ of dry matter of metabolizable energy 13.5 MJ / $\mathrm{kg}$ and crude protein - 240g/kg of DM. 
For 150 days of rearing, the bull-calves of the first group consumed $1500 \mathrm{~kg}$ of whole milk, alfalfa hay - about $90 \mathrm{~kg}$. The feeding was 2-3 times a day. The feeding scheme is shown in table 2.

Table 2. Feeding scheme for bulls of the 1st group, per 1 head per day $(\mathrm{n}=12)$

\begin{tabular}{|c|c|c|c|}
\hline Age, days & Average daily gain, $\mathbf{g}$ & Whole milk, kg & Alfalfa hay, kg \\
\hline $1-30$ & 900 & 6.0 & - \\
\hline $31-60$ & 900 & 9.0 & $0.1-0.5$ \\
\hline $61-90$ & 1000 & 10.0 & $0.6-1.0$ \\
\hline $91-120$ & 1000 & 12.0 & 1.0 \\
\hline $121-150$ & 1100 & 13.0 & 1.0 \\
\hline Total & & 1500 & 90 \\
\hline
\end{tabular}

Feeding calves of the second group during 5 months provides for feeding about $860 \mathrm{~kg}$ of milk; $218 \mathrm{~kg}$ of mixed feed, $128 \mathrm{~kg}$ of hay (Table 3). Thus, in the second group, compared to the first, there is less milk, and more other feeds.

Table 3. Feeding scheme for bulls of the 2nd (experimental) group

\begin{tabular}{|c|c|c|c|c|}
\hline $\begin{array}{c}\text { Age, } \\
\text { days }\end{array}$ & $\begin{array}{c}\text { Average } \\
\text { daily gain, } \mathbf{g}\end{array}$ & $\begin{array}{c}\text { Whole milk, } \\
\mathbf{~ k g}\end{array}$ & $\begin{array}{c}\text { Starter } \\
\text { compound } \\
\text { feed, } \mathbf{~ k g}\end{array}$ & $\begin{array}{c}\text { Alfalfa hay, } \\
\mathbf{k g}\end{array}$ \\
\hline $1-30$ & 900 & 5.0 & $0.1-0.3$ & - \\
\hline $31-60$ & 900 & 6.0 & $0.5-1.0$ & - \\
\hline $61-90$ & 1000 & 6.0 & $1.2-2.0$ & $0.5-1.0$ \\
\hline $91-120$ & 1000 & 6.0 & $2.0-2.3$ & $1.0-2.0$ \\
\hline $121-150$ & 1200 & 6.0 & 2.5 & 2.0 \\
\hline Total & - & 860 & 218 & 128 \\
\hline
\end{tabular}

From 6 months of age, calves of both groups are transferred to the same feeding without milk. As a result, until the age of 12 months, the calf consumes on average $420 \mathrm{~kg}$ of cereal-and-legume hay, $420 \mathrm{~kg}$ of haylage, $1110 \mathrm{~kg}$ of corn silage, $432 \mathrm{~kg}$ of compound feed, $33 \mathrm{~kg}$ of molasses and $6.6 \mathrm{~kg}$ of table salt (Table 4).

Table 4. Feeding scheme for bulls of both groups of 6-12 months of age with average daily gains of $1000-1200 \mathrm{~g}$

\begin{tabular}{|c|c|c|c|c|c|c|}
\hline $\begin{array}{c}\text { Age, } \\
\text { months }\end{array}$ & $\begin{array}{c}\text { Cereal } \\
\text { and } \\
\text { legume } \\
\text { hay, kg }\end{array}$ & $\begin{array}{c}\text { Haylage, } \\
\mathbf{k g}\end{array}$ & $\begin{array}{c}\text { Corn } \\
\text { silage, } \mathbf{k g}\end{array}$ & $\begin{array}{c}\text { Compoun } \\
\mathbf{d} \text { feed, } \\
\mathbf{~ k g}\end{array}$ & $\begin{array}{c}\text { Molasses, } \\
\mathbf{k g}\end{array}$ & $\begin{array}{c}\text { Table salt, } \\
\text { g }\end{array}$ \\
\hline 6 & 2.5 & 1.0 & 3.0 & 2.5 & 0.1 & 30 \\
\hline 7 & 2.5 & 2.0 & 5.0 & 2.7 & 0.2 & 40 \\
\hline 8 & 3.0 & 3.0 & 8.0 & 2.7 & 0.2 & 45 \\
\hline $9-10$ & 3.0 & 4.0 & 10.0 & 3.0 & 0.3 & 50 \\
\hline $11-12$ & 3.0 & 4.0 & 11.0 & 3.5 & 0.3 & 55 \\
\hline Total & 420 & 420 & 1110 & 432 & 33 & 6600 \\
\hline
\end{tabular}

In the course of the experiment, we took in-to account:

- live weight and weight gains of bulls by monthly weighing; 
- chemical analysis of feed (determination of dry matter, crude protein, fat, fiber, calcium, phosphorus, carotene in accordance with the requirements of the Russian Federation standard), calculation of the content of metabolizable energy and EFU;

- feed costs by growth periods every ten days by conducting control feeding;

- the cost of the ration in accordance with the prices for feed on the farm;

- the cost of feed per $1 \mathrm{~kg}$ of weight gain;

- labor costs for the preparation and distribution of feed;

- the state of health of the calves;

- quality indicators of meat (slaughter yield, chemical composition, qualitative composition of fat), the amount of fat in various parts of the carcass.

- visual inspection of the carcass.

The shape of the body should be round; musculature (well) developed; the bones of the body are hidden by the musculature and cannot be seen. The colour of the meat is light pink. Basting fat is thin and intermittent; clear deposits of fat in the kidney and pelvic cavity, on the ribs and sometimes on the thighs. Carcass yield is $49-56 \%$. The intensity of the colour of the meat is checked (method of Fewson and Kirsammer).

\section{Results and discussion}

All calves consumed milk in full. The palatability of hay and starter compound feed gradually increased. The animals of the first control group had an average body weight at birth of $32.5 \pm 1.0 \mathrm{~kg}$, at 1 month of age $53.1 \pm 1.3 \mathrm{~kg}$, at 2 months and following, respectively: $77.7 \pm 1$, 8; $108 \pm 2.1 ; 147.8 \pm 3.2$ and $186.3 \pm 3.3$. The average daily weight gain from 1 to 5 months was, respectively: 686.1; 819.2; 1012.8; $1325.5 ; 1284.7$ g. The average weight gain for the first 5 months was $1025.6 \mathrm{~g}$ (Table 5).

Table 5. Live weight and average daily weight gain of bulls

\begin{tabular}{|c|c|c|c|c|}
\hline \multirow{2}{*}{ Age, months } & \multicolumn{2}{|c|}{ 1 group (control) } & \multicolumn{2}{c|}{ 2 group (experimental) } \\
\cline { 2 - 5 } & live weight, kg & $\begin{array}{c}\text { average daily } \\
\text { weight gain, }\end{array}$ & live weight, kg & $\begin{array}{c}\text { average daily } \\
\text { weight gain, g }\end{array}$ \\
\hline At birth & $32.5 \pm 1.0$ & - & $30.4 \pm 0.7$ & - \\
\hline 1 & $53.1 \pm 1.3$ & $686.1 \pm 8.2$ & $56.6 \pm 1.3^{*}$ & $872.2 \pm 3.4^{*}$ \\
\hline 2 & $77.7 \pm 1.8$ & $819.2 \pm 9.1$ & $87.1 \pm 1.5^{*}$ & $1016.7 \pm 5.4^{*}$ \\
\hline 3 & $108 \pm 2.1$ & $1012.8 \pm 13.4$ & $121.7 \pm 1.9^{*}$ & $1152.8 \pm 3.7^{*}$ \\
\hline 4 & $147.8 \pm 3.2$ & $1325.5 \pm 11.5$ & $160.7 \pm 1.9$ & $1300.0 \pm 7.4$ \\
\hline 5 & $186.3 \pm 3.3$ & $1284.7 \pm 10.8$ & $199.9 \pm 2.3$ & $1308.3 \pm 8.9$ \\
\hline 12 & $410.32 \pm 5.43$ & $1056 \pm 10.9$ & $443.31 \pm 1.72^{* *}$ & $1142.8 \pm 15.6^{* *}$ \\
\hline
\end{tabular}

Note: * - differences at $\mathrm{p}<0.05$; ** - differences at $\mathrm{p}<0.01$

The gross increase in live weight in calves of the 1 st group was $153.8 \pm 3.5 \mathrm{~kg} /$ head at low costs per $1 \mathrm{~kg}$ of growth - $3.40 \mathrm{EFU}$.

Animals of the second experimental group had an average live weight at birth, at 1-, 2-, $3-$, 4- and 5 months of age, respectively: $30.4 \pm 0.7$; $56.6 \pm 1.3$; $87.1 \pm 1.5$; $121.7 \pm 1.9$; $160.7 \pm 1.9 ; 199.9 \pm 2.3 \mathrm{~kg}$.

Average daily gains in live weight by months of the test period were, respectively: $872.2 \pm 3.4 ; 1016.7 \pm 5.4 ; 1152.8 \pm 3.7 ; 1300.0 ; 1308.3 \mathrm{~g} /$ head. On average, over 5 months, the calves gained $1130 \mathrm{~g}$ of live weight / head per day, and consumed $3.71 \mathrm{EFU}$ per $1 \mathrm{~kg}$ of weight gain.

The gross live weight gain in calves of the second group was $169.5 \mathrm{~g}$, which is higher than in the first group by $13.6 \mathrm{~g}(\mathrm{p}<0.01)$.

The cost of feed spent on $1 \mathrm{~kg}$ of live weight gain in group 1 was 173.06 rubles, and in group 2 - 107.79 rubles, or $37.7 \%$ lower. 
To study the meat qualities, 3 heads from each group were killed. The live weight of bull-calves during slaughter in the first group was $201.1 \mathrm{~kg}$, in the second - $212 \mathrm{~kg}$. The carcasses of calves we classified as the first category of quality with the shape of the body: round, the muscles are well developed, the spinous processes of the vertebrae do not protrude, the color of the meat is milky- pink, the intensity of the colour of meat in the first group is 72.1 extinction units, in the second group - 71.2 extinction units, which corresponds to the standard. Fat deposition was observed in the area of the kidneys and in some places on the ribs (Table 6).

Table 6. Study of the meat qualities of bull calves at 5 months of age, $n=3$

\begin{tabular}{|c|c|c|}
\hline Item & 1 group (control) & 2 group (experimental) \\
\hline Live weight at slaughter, kg & $201.1 \pm 1.7$ & $212.0 \pm 2.4 * * *$ \\
\hline Carcass weight, kg & $102.91 \pm 1.8$ & $110.21 \pm 2.0^{*}$ \\
\hline Meat output, \% & 51.2 & 52.5 \\
\hline $\begin{array}{c}\text { Colour intensity of meat, } \\
\text { extinction units }\end{array}$ & 72.1 & 71.2 \\
\hline Calcium, mg / $100 \mathrm{~g}$ & 11.0 & 10.0 \\
\hline Phosphorus, mg / 100 g & 71.0 & 73.0 \\
\hline Sodium, mg / $100 \mathrm{~g}$ & 68.0 & 64.0 \\
\hline Potassium, mg / $100 \mathrm{~g}$ & 345 & 338 \\
\hline Magnesium, mg / 100 g & 19.0 & 20.0 \\
\hline Manganese, mg / 100 g & 26.0 & 28.0 \\
\hline Iron, $\mathrm{mg} / 100 \mathrm{~g}$ & 2.2 & 2.4 \\
\hline Protein, \% & 20.91 & 19.34 \\
\hline
\end{tabular}

In bull calves of the first group, the carcass weight averaged $102.91 \mathrm{~kg}$, meat yield $51.2 \%$. In animals of the same age of the second group it was $110.21 \mathrm{~kg}, 52.5 \%$, respectively. In the first and second groups, the meat $\mathrm{pH}$ was 5.84 and 5.69 units, respectively.

The content of minerals in the average sample of meat in bulls of the first and second groups was as follows, mg / 100 g: calcium - 11.0 and 10.0; phosphorus - 71.0 and 73.0; sodium - 68.0 and 64.0; potassium - 345 and 338; magnesium - 19.0 and 20.0; manganese 26.0 and 28.0; iron - 2.2 and 2.4 (at $\mathrm{P}>0.05$ ).

The mass fraction of protein in bulls of the first and second groups was equal: $20.91 \%$ and $19.34 \%$. There are no differences in amino acid composition between the groups.

\section{Conclusions}

Different types of bull calves rearing in the first 5 months of life led to significant differences in the growth and development of the whole organism and all its individual organs and tissues, mainly in favour of bulls raised with replacement of part of the milk with vegetable feed, and subsequently had a decisive influence during the period from 6 to 12 months of their life with the same type of feeding and keeping. Weight gain from five months to 12 months of age in group 1 was $225.05 \mathrm{~kg}$, and in group 2 - $243.41 \mathrm{~kg}$, i.e. $18.36 \mathrm{~kg}$ more. For the same period the average daily live weight gain of bulls of group 
1 was $1056 \mathrm{~g}$, and group $2-1142.8 \mathrm{~g}$, or $85.4 \mathrm{~g}$ more, or $8.2 \%(\mathrm{p}<0.01)$. At the sixth month of life, the calves of the 1st group had an average live weight of $223.77 \pm 4.56 \mathrm{~kg}$, and the analogs of the 2nd group, $237.45 \pm 2.46 \mathrm{~kg}$, i.e. slightly (by $13.68 \mathrm{~kg}$ ) more (at $\mathrm{td}=$ 2.6). At 12 months of age, the bulls of the 1 st group had a live weight of $410.55 \pm 4.97 \mathrm{~kg}$, and the peers of the 2nd group, who had better development of all organs in the first 5 months of rearing in the milk period, had a live weight of $442.91 \pm 1,66 \mathrm{~kg}$ and significantly exceeded group 1 by $32.36 \mathrm{~kg}$ (differences at $\mathrm{td}=6.2$ ). The weight gain for the 12-month period of growing and fattening in the 1st group was $377.82 \pm 5.43 \mathrm{~kg}$, and among the peers of the 2 nd group - $412.91 \pm 1.72$. Differences in weight gain in favour of the latter amounted to $35.09 \mathrm{~kg}$ with a high reliability $(\mathrm{p}<0.01)$. After the milk feeding period at 6-12 months of life in the bulls of the 2nd group, this provided a lower feed consumption per unit of weight gain and an increased cost of meat products by $8.2 \%$ compared with the 1st group, and for all 12 months by $9.3 \%$.

It has been established that the rearing system with a decrease in the drinking of whole milk and abstinence with giving roughage for the first 2 months of life, promotes the intensification of the growth of animals for the entire twelve-month period of life, leads to an increase in meat yield, a decrease in feed consumption per unit of weight gain and increase in the profitability of production by $8-9 \%$, therefore it is recommended for the production of high-quality beef.

\section{References}

1. M. Modzelewska-Kapituła, K. Tkacz, Z. Nogalski et al., Livestock Science, 243, 104383 (2021)

2. K. Manni, M. Rinne, A. Huuskonen, P. Huhtanen, Meat Sci., 143, pp. 184-189 (2018)

3. A. Listrat, B. Lebret, I. Louveau, T. Astruc, M. Bonnet, L.Lefaucheur, B. Picard, J. Bugeon, Sci. World J., 2016, pp. 1-14 (2016)

4. M.R. Hunt, J.F. Legako, T.T.N. Dinh, A.J. Garmyn, T.G.O'Quinn, C.H. Corbin, R.J. Rathmann, J.C. Brooks, M.F. Miller, Meat Sci, 116, pp. 91-101 (2016)

5. A.P.B. Fruet, A. De Mello, F. Trombetta, F.S Stefanello,C.S. Speroni, D.P. De Vargas, A.N.M. De Souza, A.G. Rosado Júnior,C.J. Tonetto, J.L. Nörnberg, Meat Sci, 145, pp. 121-126 (2018)

6. D. Bureš, L. Bartoň, Livest. Sci., 214, pp. 231-237 (2018)

7. J. Soulat, B. Picard, S. Léger, V. Monteils, J. of Animal Sci., 94, pp. 1712-1726 (2016)

8. S. Savoia, A. Brugiapaglia, A. Pauciullo, L. Di Stasio, S.Schiavon, G. Bittante, A. Albera Meat Sci, 153, pp. 75-85 (2019)

9. Y.N. Kolesnik, N.A. Yurina, D.A. Yurin, A.A. Danilova, V.P. Korotky, V.A. Ryzhov, A.S. Zenkin, International J. of Pharm. Research, 10 (4), pp. 655-660 (2018)

10. V. A. Reis, R. A. Reis, M. M. Ladeira et al., Meat Sci., 160, 107962 (2020)

11. A. DiCostanzo, J. of Animal Sci., 88(13), pp. E1-E2 (2010)

12. P. Veysset, M. Lherm, D. Bébin, Organic Agriculture, 1, pp. 1-16 (2011) 